\title{
The wisdom of the crowd in funding: information heterogeneity and social networks of crowdfunders
}

\author{
Friedemann Polzin • Helen Toxopeus • Erik Stam
}

Accepted: 10 July 2016 / Published online: 25 January 2017

(C) The Author(s) 2017. This article is published with open access at Springerlink.com

\begin{abstract}
Crowdfunding has enabled large crowds to fund innovative projects. This type of funding might tap into the wisdom of crowds who were previously disconnected from the funding process. We distinguish between in-crowd and out-crowd funders (with and without ties to project creators) in order to test for heterogeneity in their information use. Based on the analysis of a large-scale survey amongst project funders, this paper shows that in-crowd investors rely more on information about the project creator than out-crowd investors. Outcrowd investors do not seem to attach more importance to information about the project itself than in-crowd investors, except in the case of donation-based crowdfunding. For financial return crowdfunding, financial information becomes less important once a strong relationship with the project creator is established. Our study allows project creators to target information to specific audiences based on their relationship strength across different types of crowdfunding projects.
\end{abstract}

F. Polzin $(\bowtie) \cdot$ E. Stam

Utrecht University School of Economics (USE), Kriekenpitplein 21-22, PO Box 80125, 3508 TC Utrecht, The Netherlands e-mail: f.polzin@uu.nl

F. Polzin

Sustainable Finance Lab (SFL), Kriekenpitplein 21-22, PO Box 80125, 3508 TC Utrecht, The Netherlands

\section{H. Toxopeus}

Impact Centre Erasmus (ICE), Erasmus School of Accounting and Assurance, Burgemeester Oudlaan 50, 3062 PA Rotterdam,

The Netherlands
Keywords Crowdfunding $\cdot$ Social networks $\cdot$ New ventures $\cdot$ Entrepreneurial finance $\cdot$ Information asymmetries

JEL codes G23 $\cdot$ G32 $\cdot$ D82 $\cdot$ D85 $\cdot$ L26

\section{Introduction}

The funding of innovative start-ups has always been challenging due to a lack of track record, collateral and technological uncertainty (Engel and Stiebale 2014; Hall 2002; Giudici and Paleari 2000). More generally, small- and medium-sized firms face greater capital constraints than large firms, lacking access to market-based funding due to the high fixed costs associated with issuing equity and the unwillingness of institutional investors to take small holdings. This leaves start-ups highly dependent on bank credit, venture capital funds, angel investors and bootstrapping for their liquidity needs (Chittenden et al. 1996; Ebben and Johnson 2006; Giudici and Paleari 2000; Keasey and McGuinness 1990). Access to bank credit has become more transactional in recent decades with increased centralization and computerised assessment of creditworthiness (Bhidé 2010) and is often restricted due to a lack of profit and collateral. This shift severely affects innovative small firms due to their disproportionate reliance on soft information in the lending process (Brancati 2014; Cosci et al. 2016). Furthermore, the willingness of venture capitalists to fund start-ups is often limited to certain sectors (Huyghebaert et al. 
2007) and there is evidence that the financial crisis has dampened their willingness to invest, particularly in follow-up rounds (Block and Sandner 2009; Cowling et al. 2016; Migendt et al. 2014). Structural financing constraints for small firms impede economic growth when firms downplay their growth strategy to match available funds (Beck and Demirguc-Kunt 2006; Binks and Ennew 1996; Chittenden et al. 1996; Rostamkalaei and Freel 2015).

The rise of crowdfunding over the past decade in part addresses this funding gap by offering entrepreneurs an alternative to traditional finance channels. Crowdfunding caters well to innovative, opaque, small firms and makes use of social networks in the funding process (Colombo et al. 2015; Vismara 2016a). It builds on and expands beyond the traditional 'in-crowd' of family and friends by allowing both in- and out-crowd investors to provide finance through digital platforms (Bruton et al. 2015; Salomon 2016). Furthermore, it has lowered the transaction costs for entrepreneurs to collect small investment amounts from a dispersed set of investors and is becoming an increasingly sizable source of funding for start-ups and other bottom-up initiatives in the economy (Massolution 2015; Wardrop et al. 2015). However, it is unclear whether crowdfunding provides access to the wisdom of the crowd, or whether it opens up a wider audience of fools alongside the usual family and friends in-crowd.

In line with the growth of crowdfunding, academic research directed at understanding this phenomenon has emerged in recent years (Moritz and Block 2016). Much of this literature focuses on success factors driving crowdfunding campaigns, such as the role of early contributions (Agrawal et al. 2015; Cholakova and Clarysse 2015; Colombo et al. 2015). There is also considerable attention on the role of social networks in crowdfunding (Agrawal et al. 2015; Horvát et al. 2015; Hui et al. 2014 ) and on overcoming informational asymmetries (Ahlers et al. 2015; Lin et al. 2012; Vismara 2016b). Lacking attention until now is the bridge between these two topics, namely, how social networks affect the type of information used by investors in crowdfunding decision making. Although there are suggestions regarding crowdfunding information mechanisms and the role of social networks (Ter Wal et al. 2016), there is little empirical evidence about the type of information that funders use to make investment decisions.
Are crowdfunders well informed about the project they invest in or are they jumping on a band-wagon set in motion by other investors in a campaign?

This study offers the first detailed empirical analysis on heterogeneity in information use by crowdfunders and how this is affected by their social networks. The ability to distinguish between investors based on their interpersonal ties to the entrepreneur offers insights into the application of theories about information asymmetries and social networks in funding decisions and serves as input for public policy for entrepreneurship and finance. Our main research question is: How does the type of information used by crowdfunders vary with the strength of their ties to project creators?

This article is structured as follows: first, we review the relevant literature and introduce the theoretical framework. Next, we present the research design including our quantitative research approach and data. We then display the results which form the basis for the conclusions in the final section.

\section{Literature review and theoretical framework}

\subsection{Signalling in early-stage finance and information cascades}

The way entrepreneurs obtain capital when forming a new firm has important implications for future performance (Bosma et al. 2004; Cassar 2004). Their search for external finance is characterised by agency problems between the entrepreneur and funder due to information asymmetries that lead to adverse selection and moral hazard (Denis 2004; Jensen and Meckling 1976; Parker 2009). This is especially the case for new firms that face high financing costs (Rostamkalaei and Freel 2015) driven by cumbersome information gathering, a lack of track record and, often, collateral (Blumberg and Letterie 2007; Cassar 2004).

Scholars suggest signalling can overcome these agency problems (Akerlof 1970; Amit et al. 1990; Gompers 1995; Myers and Majluf 1984; Stiglitz and Weiss 1981). Signalling can take place using different kinds of information, for example, the availability of patents and prototypes or the track record of entrepreneurial team (Audretsch et al. 2012; Becker-Blease and Sohl 2015; Busenitz et al. 2005; Gompers and Lerner 2001; Spence 1973). Many studies in the signalling literature establish a positive relationship between 
early-stage investments and firm success (Bernstein et al. 2016a; Bosma et al. 2004; Kerr et al. 2014; Kortum and Lerner 2000; Samila and Sorenson 2010) and link an entrepreneur's characteristics, such as human capital, to venture performance (Becker-Blease and Sohl 2015; Ouimet and Zarutskie 2014; Pukthuanthong 2006). Bernstein et al. (2016b) examine venture attributes used to signal quality to investors, i.e. the team, track-record of the venture and identity of current investors. They suggest that information about the person(s) behind the venture is crucially important for obtaining external finance, which is in line with the practice of VC and business angels (Alexy et al. 2012; Becker-Blease and Sohl 2015; Vismara 2016a).

Crowdfunding, ${ }^{1}$ as a new form of seed finance, acts as a platform (agent) between investors and entrepreneurs (Bruton et al. 2015; Cumming et al., 2015b; Harrison 2013; Salomon 2016). A growing interest and body of research is emerging into this new form of entrepreneurial finance (for reviews see Kuppuswamy and Bayus 2015; Moritz and Block 2016). Crowdfunding combines features of a two-sided market platform with underlying networking technologies. The real-time, open and online insight into the commitment of previous funders, as well as extensive targeted descriptions of the fundraising campaign, is a specific signal of crowdfunding (Bruton et al. 2015). The quality of these signals as input into investment decisions is questionable since the crowd might neither have expertise in production, marketing and competition nor are they likely to invest in due diligence given high fixed costs (Belleflamme et al. 2013; Vismara 2016a). As such, the wisdom of the crowd is not self-evident. On the one hand, the crowd could represent new customers, delivering knowledge about the market potential of an offering by signing up as funders. On the other, they could be free-riding on the - potentially unwise - investment decisions of others, and 'herd' without adding

\footnotetext{
${ }^{1}$ Following previous work we distinguish four types of crowdfunding (Ahlers et al. 2015; Belleflamme et al. 2014; Mollick 2014; Nesta 2014): Purely donation-based crowdfunding exists that involves only intangible returns. Reward-based crowdfunding (or pre-ordering) consists of pledging an amount of money in exchange for future products. Lending-based crowdfunding can be compared to micro-loans, where the backer lends a certain amount of money to the project creator. Equity-based crowdfunding issues shares in the company behind the call, which are distributed amongst the funders according to the value of their contributions. The latter two are combined throughout this paper and referred to as 'financial crowdfunding'.
}

any new information to a decision process (Bikhchandani et al. 1992).

Hornuf and Schwienbacher (2015) find that specific kinds of information, such as updates to investors, significantly drive investment as funders update their preferences in the light of project assessment. Moritz et al. (2015) examined investor communication in equity crowdfunding, highlighting that perceived sympathy, openness and trustworthiness in the relationship between venture and investor reduced perceived information asymmetries. They also found that third-party communication influences the decision-making process of crowdfunders. Furthermore, allowing crowdfunders to adjust privacy settings regarding information about their contribution deters some investors but increases average contribution size (Burtch et al. 2015).

This suggests that some form of quality signalling between project creator and crowdfunder occurs which relates to the general notion of the 'wisdom of the crowd' in funding decisions (Mollick and Nanda 2015; Surowiecki 2005). But how does the crowd gather its 'wisdom'? Literature on investment processes suggest that this is facilitated by the social networks of both entrepreneur and investor (Alexy et al. 2012; Colombo et al. 2015; Ter Wal et al. 2016; Uzzi 1999).

\subsection{Ties that bind, ties that blind: social networks and information}

Social networks strongly influence an entrepreneur's funding success as these provide access to resources such as finance, knowledge and partners (Davidsson and Honig 2003; Dubini and Aldrich 1991; Huang and Knight 2015; Kwon and Arenius 2010; Shane and Cable 2002). Social network theory provides a possible lens to study the role of information in the relationship between funder and venture (Granovetter 1973; Hoang and Antoncic 2003; Jack and Anderson 2002; Kwon and Arenius 2010; Uzzi 1999). Granovetter (1973, p. 1361) defines the notion of 'strength' of interpersonal ties based on 'a combination of the amount of time, the emotional intensity, the intimacy and the reciprocal services which characterize the tie'.

Social networks, comprising both strong and weak ties, may affect the type of information used in a financing decision through three mechanisms. First, the funder's motivation for investing, for example, for financial return or to strengthen an existing relationship, will affect the information required (Belleflamme et al. 
2014; Shane and Cable 2002). Second, the extent to which interpersonal ties develop and enforce common norms of behaviour will affect the perceived moral hazard of an investment (Bernstein et al. 2016a; Granovetter 2005; Uzzi 1999). This may make obtaining information about the entrepreneur more attractive than information about the project, its objectives, risk and finance. Third, the way in which quality signals are disseminated and received may vary based on the strength of the relationship, affecting informational asymmetries (Ter Wal et al. 2016). For example, funders with weak ties to the project creator consume novel information more readily than those with stronger ties (Alexy et al. 2012; Granovetter 1973; Ter Wal et al. 2016). However, in situations of risk and uncertainty, reliance on multiple, more trustworthy information sources may favour funders with stronger ties to the project creator (Centola and Macy 2007; Ter Wal et al. 2016).

Crowdfunding could be classified as a new form of relationship-based financial intermediation, exploiting the local knowledge and trust embedded in social networks to provide quality signals about the project creator and their project. The mechanisms at play could be similar to those seen in venture capital and angel investment. Relationships are built between financier and venture as well as between syndicates of financiers to mitigate information asymmetries (Alexy et al. 2012; Gompers 1995; Gompers and Lerner 2001; Yao-Wen 2010). Social ties between investors are formed every time they are attracted to the same target company (Sorenson and Stuart 2008; Ter Wal et al. 2016).

Several scholars (Agrawal et al. 2015; Belleflamme et al. 2014; Lin et al. 2012; Mollick 2014; Ordanini et al. 2011; Vismara 2016a) show that the size of a founder's social network is positively associated with the capital raised for a project and the subsequent success of the project in both reward-based and equity crowdfunding; this effect does not hold in a donation-based setting (Burtch et al. 2013; Kuppuswamy and Bayus 2015).

Furthermore, the relationship between funders and project creators affects investment sequencing through information cascades. Individual funders possess different levels of information; hence, some investors have an advantage over others (Cumming et al. 2015a; Hildebrand et al. 2016). When professional investors with industry experience and track record enter relatively early in a crowdfunding campaign, their public visibility attracts other investors (Vismara 2016b), in a similar way as in other online market places (Dellarocas 2003; Lin et al. 2012). This suggests that the quality indication process with crowdfunding is staged, with an in-crowd to out-crowd sequence, using different types of information and levels of expertise to make a funding decision.

\subsubsection{In-crowd information needs}

We define the in-crowd as those project funders who have strong or weak interpersonal ties with the project creator. On crowdfunding platforms, investors base their decisions on information provided by the project creator in the form of updates during the campaign and on the investment behaviour and comments of other crowd investors (Hornuf and Schwienbacher 2015). In-crowd information requirements could be affected by the three mechanisms outlined above: funder motivation, project creator intentions and information flow.

Firstly, the in-crowd may have different motivations than wanting to contribute to a successful project, such as reinforcing their relationship with the project creator, social obligation or altruism (Belleflamme et al. 2014; Gartner et al. 2011; Klyver et al. 2016; Shane and Cable 2002). This could make them less inclined to search for quality signals about the project itself and focus more on information about the person behind the project. Secondly, we expect that funding decisions embedded within a social network will decrease fears of negative behaviour by the project creator (Bernstein et al. 2016a; Granovetter 1985; Uzzi 1999). This motivates the funder to seek information about the person behind the venture, increasing trust along with relationship strength. Third, and central to our argument, social networks support the flow of information which signal quality of projects and entrepreneurs (Alexy et al. 2012; Ter Wal et al. 2016). Instead of relying on formal sources of information (such as project websites and media), in-crowd funders may place higher weight on information coming through their personal relationship with the project creator, which they expect to be more accurate and proprietary, giving them an edge over publicly available information. In line with Ahlers et al. (2015), Cholakova and Clarysse (2015) and Cumming et al. (2015b), we expect the in-crowd to gather (soft) information about the characteristics of a project's management (track record, size or level of education) as this affects probability of success of the venture. Due to existing ties, obtaining and processing 
this person-to-person information about management or initiators is less costly than for out-crowd funders. Additionally, relationships may imply a longer-term commitment to the entrepreneur and therefore a longer term perspective on the costs and benefits of investing in information gathering about the entrepreneur (Boot 2000; Brancati 2014; Scholtens 1999).

Hypothesis 1 In-crowd funders are more likely to rely on information about the person(s) behind the project than out-crowd funders.

\subsubsection{Out-crowd information needs}

We define the out-crowd as those project funders who have no personal ties to the project owner. We expect this to lead to different information needs through the same three mechanisms. First, without the funding decision embedded in a social relationship, the motivation is more likely to be based on expected results, such as financial return (Cholakova and Clarysse 2015), a finished product or societal impact rather than social capital (Apinunmahakul and Devlin 2008) or community benefits (Belleflamme et al. 2014). Information about the project, its objectives, finance and risk will be more relevant as it gives insight into the expected return of the project (Ahlers et al. 2015; Belleflamme et al. 2013, 2014). Secondly, information gathering about the project team is unlikely to reduce moral hazard as there is no relationship to enforce social reward or punishment (Belleflamme et al. 2014; Vismara 2016a). Third, as the out-crowd lacks direct insights from the project creator, they depend on information that reaches them through formal direct (project websites, newsletters) or indirect (media) channels (Hornuf and Schwienbacher 2015). Information about the project creator obtained through formal channels is often perceived as less trustworthy and more difficult to interpret as a quality signal than when obtained through interpersonal ties. As such, it loses its advantage over more general information about the project and its objectives (Hornuf and Schwienbacher 2015; Vismara 2016a). We expect out-crowd funders to be less motivated than incrowd funders to gather information about the project team and to instead focus more on 'traditional' quality signals such as the nature of the project or venture and its strategy (Ahlers et al. 2015; Hornuf and Schwienbacher 2015).
Hypothesis 2 Out-crowd funders are more likely to rely on information about the project and its objectives than in-crowd funders.

Furthermore, we expect out-crowd funders to rely more on information about financial planning and risk than in-crowd funders due to stronger instrumental (results-based) motivation and a lack of personal access to the project owner. A recent study on equity crowdfunding shows that the decision to invest is positively associated with the funders' interest in rewards (Cholakova and Clarysse 2015). Ahlers et al. (2015) study the effectiveness of quality attributes and the level of uncertainty in offer documents used to encourage (small) investors to invest in an equity crowdfunding context. They highlight the importance of financial projections for crowdfunding success. The absence of ties to the project owner creates an incentive to look for alternative, objective quality signals and leads funders to investigate information about financial planning and risk more thoroughly than in-crowd funders (Ahlers et al. 2015; Busenitz et al. 2005; Hornuf and Schwienbacher 2015).

Besides providing a quality signal, information about financials and risk can also reduce the perceived risk of moral hazard by revealing the commitment level of the project creator, such as whether or not they provide personal collateral and/or invest their own resources (Blumberg and Letterie 2007). We therefore expect that out-crowd funders rely more on information about financial planning and risks than in-crowd funders, looking both for quality signals and to reduce perceived moral hazard risk.

Hypothesis 3 Out-crowd funders are more likely to rely on information about financial planning and risks than in-crowd funders.

\section{Methodology}

\subsection{Research design}

In this paper, we seek to understand the effect of the strength of interpersonal ties on the information used by crowdfunders. In order to test the hypotheses formulated above, we constructed the analytical model presented in Fig. 1. Most of the literature to date uses project-level investment data that includes varying degrees of information about the project and its creator. However, this type of data does not convey much information about 


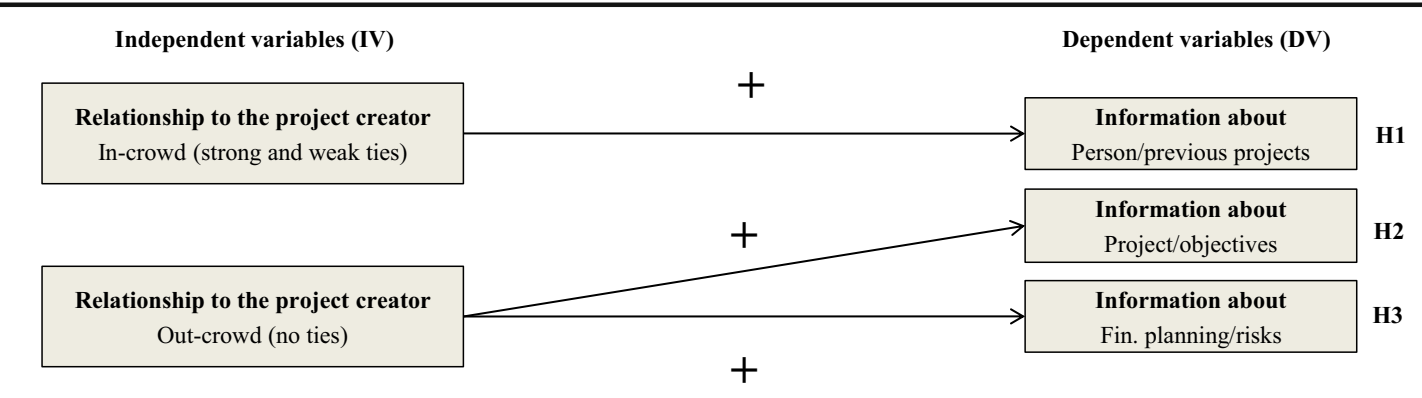

Control variables
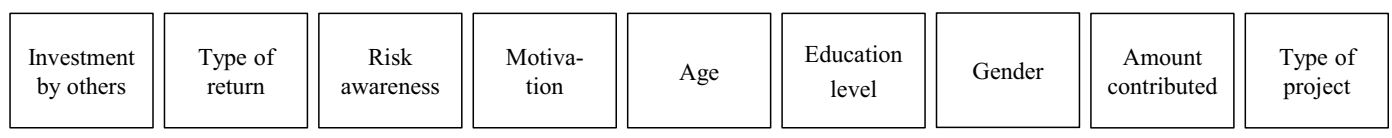

Fig. 1. Analytical model

the project funders themselves. To analyse the hypothesised relations, we used a large-scale survey of crowdfunders (Cholakova and Clarysse 2015; Mollick 2015). We note that this methodological approach is potentially vulnerable to common method bias (i.e. gathering all information for this analysis via one survey) which has been shown to affect survey data (Podsakoff et al. 2003). Whilst we could not conceptually identify any underlying factors that the predictor and criterion variables had in common, we adopted several measures to reduce potential bias. We started by minimizing item ambiguity which included avoiding vague concepts, complicated syntax and unfamiliar terms. We deliberately used simple, specific and concise questions to measure the constructs. The respondents were also guaranteed anonymity.

\subsection{Data}

We use data from a large-scale survey called the 'National Crowdfunding Research' conducted in 2013 in The Netherlands with 1278 individual respondents. ${ }^{2}$ Respondents were surveyed regarding their participation in crowdfunding, on topics such as their investments, motivation and use of information in investment decisions. It targeted both active crowdfunders as well as non-crowdfunders. The research was organised by the Dutch National Crowdfunding Association. A snowball sampling method was used which drew on

\footnotetext{
${ }^{2}$ The questionnaire is published at: http://www. crowdfundingonderzoek.nl/
}

the personal and organisational networks of participating organisations. About 300 responses included our variables of interest (see Fig. 1). Of these, the respondents had participated in either donation, reward-based or financial return (debt and equity) crowdfunding through all types of platforms (mainly, but not only, Dutch platforms). The sample is representative of other active crowdfunders in terms of age and education (Mollick 2015).

\subsubsection{Dependent variables}

We created several dependent variables as proxies for use of information, with a distinct question in the survey where respondents rated the importance of six different types of information in their decision to crowdfund. These types of information were (1) information about the project or the company, (2) information about the objectives of the project or the company (Ahlers et al. 2015; Hornuf and Schwienbacher 2015), (3) information about the person or organization behind the project or the company, (4) information about previous projects of the person or organization behind it (Bernstein et al. 2016b; Cholakova and Clarysse 2015), (5) information about the financial planning of the project or the company, and (6) information about the risks associated with the project or the company (Ahlers et al. 2015). Using factor analysis, we created the following additional 'information use' dependent variables from these responses: (1) information about project and objectives 'infoprojobj', (2) information about person and their 
track record 'infopersprev' and (3) information about financial planning and risks 'infofinrisk'.

\subsubsection{Independent variables}

To determine the influence of interpersonal ties on the information use of funders, we included the relationship to project creator as an independent variable ('What was your relationship with the project owner or business owner before making your financial contribution through crowdfunding?'). We combine the individual answer categories to create new variables measuring relationship strength, aggregating different types of relationship to strong ties, weak ties or no ties (a similar approach has been taken by Klyver et al. 2016). 'Strong ties' included family, friends, initiator of the project or employee (Kuppuswamy and Bayus 2015). 'Weak ties' consist of people who indicate that they know the person behind the project or are a friend of friend, a business relationship, customer, fan or visitor (Bruton et al. 2015). If there was no relationship, we coded it as 'no ties'. We created one extra answer category based on manual answers entered in the category 'other', namely, 'initiator/employee'. In the case that there were multiple relationships indicated, we always selected the strongest (i.e. if someone responded both 'friend' and 'fan', we used 'friend').

\subsubsection{Control variables}

To account for the effect of other characteristics of the funders, we include a number of control variables from the survey such as age, gender (Klyver et al. 2016), education level (Mollick 2014), type of project invested in, amount funded, type of return (donation, in-kind, financial) (Vismara 2016a, 2016b), motivation, investment of others and risk awareness.

Following earlier work (Calic and Mosakowski 2016; Hörisch 2015), we distinguish between for-profit, social, cultural and ecological projects and coded all projects into these categories as follows: (1) For-profit, (2) Social, (3) Cultural, (4) Ecological. Multiple answers were not coded. We asked an external researcher to validate our coding and used this feedback to improve our coding process (Patton 2002). If there was only a description of the specific project (without a name), we searched for a crowdfunding project which matched that description and the time period, and if we found a plausible match, we coded this project.
By including instrumental (vs. value-based) motivation as a control variable, we control for one of the mechanisms through which we expect relationship strength to influence the type of informational need. We do this in order to focus on the behavioral intention of the project funder and quality signals as key mechanisms to overcome informational asymmetries in our model (Vismara 2016a). We use 'importance of security of getting a promised return' (securityreturn) as a proxy for instrumental motivation. Consistent with cognitive evaluation theory, the intrinsic motivation of lenders to provide capital is undermined when entrepreneurs focus on future extrinsic rewards associated with lending (Allison et al. 2015). We also control for the influence of others investing in the project (herding effect) (Bikhchandani et al. 1992; Vismara 2016b) by including the variable 'knowing the financial contributions made by others' (knowingfincontriboth) in our analysis.

Finally, we control for risk awareness (professionalism) of crowdfunders, since we expect experienced investors to use more information than amateur investors. We use the statement 'I keep in mind the consideration that to invest through crowdfunding in a company can be a high risk investment' as a proxy for risk awareness.

\subsubsection{Data analysis}

Most variables were assessed on a 5-point Likert scale (Dillman 2000). The level of ties (strong, weak and no ties) and type of crowdfunding (donation, reward and financial return) were entered as dummy variables, with reward-based crowdfunding being the reference case. Amount invested, gender and education have different scales. The data analysis was conducted in several steps (Hair 2010). First, we thoroughly screened the dataset: cases with missing values have been excluded. Second, we recorded central variables based on our theoretical framework. Third, we used a factor analysis to determine influential variables and to eliminate redundancy amongst variables in the survey, in particular, to define factor loadings for the various dependent variables describing 'informational use'. Fourth, we conducted exploratory data analysis, highlighting how crowdfunders with different relationship strengths to the project owner (in-crowd, out-crowd; differently defined) differ with respect to the following: motivation, objectives, amount invested, personal characteristics, etc., followed by a more structured correlation analysis (see Table 3 in 
Appendix). Finally, as our dependent variable is of ordinal nature, we conducted ordered logistic regressions to determine the explanatory power of our independent variables (Agresti 2010; Hair 2010). Ordered logistic regression does not require normally distributed variables and can deal with metric and non-metric independent variables as well as non-linear effects. It also has relaxed assumptions regarding heteroskedastic variables (Hair 2010).

\section{Results}

\subsection{Descriptive statistics}

Table 2 in the Appendix provides descriptive statistics of our dependent, independent and control variables. The first three rows are our dependent variables measuring the information use of funders. The next three rows describe our independent variables (strong, weak and no ties). The remainder of the rows describe our control variables. In our full model, 283 observations report on all variables, of which 72 funders engaged in donationbased crowdfunding; 163 contributed to reward-based projects, and 48 contributed to campaigns that are expected to yield a financial return. The importance of information about the project and its objective is generally very high (mean of 4.3 ) followed by information about the entrepreneur (3.7) and information about the financial aspects and risks of the campaign (3.3). Whilst very few investors have low information needs on all dimensions, only $40 \%$ of funders score highly (4 to 5 ) on the importance of all information for their decision making. About $18 \%$ of the respondents have strong ties to the project creator, about one half have weak ties, and approximately one third of all respondents have no ties. The average amount invested lies in the range of $€ 101-$ $€ 250$. There is a slight bias towards male respondents $(63 \%)$. The average age of respondents lies in the range of 35-44 years old. Respondents are on average highly educated, holding a university bachelor degree. The correlation table including all dependent, independent and control variables is presented in Table 3 in the Appendix. Several statistically significant correlations between our dependent variables and relationship strength are reported. Some control variables are also statistically significantly correlated with at least one of the information variables.

\subsection{Determinants of information use of crowdfunders}

Our models (1-6, see Table 1) allow analysis of the importance of several types of information used by crowdfunders according to relationship strength between funder and project owner. We enter both strong and weak ties into the regression as dummy variables, using no ties as a reference case. Our results show that relationship strength has significant effects on the importance of different types of information.

First, our regression model shows that funders with strong or weak ties attach significantly higher importance to information about the project creator and their previous projects than funders with no ties. This supports our hypothesis 1 (H1). We differentiate this result across crowdfunding types in two steps. As a first step, in our regression model we add dummy variables for both financial return and donation crowdfunding, using reward-based crowdfunding as a base case (this is the largest sample). We find significantly higher information is required about the person and their previous projects for both financial return and donation crowdfunding compared to the reference reward crowdfunding case (independent of ties). As a second step, to analyse the effect of ties on information needs within each type of crowdfunding, we computed the full model again specifically for the subsets of donation-based, reward-based and financial return crowdfunding respectively (Tables 4, 5, and 6 in Appendix). For donation-based crowdfunding, we find no statistically significant effect of relationship strength on information about the person behind the project and their track record. Within reward-based crowdfunding, both funders with strong and weak ties attach more importance to the information about the project creator than those with no ties. In financial return crowdfunding campaigns, funders with strong ties attach more importance to information about the person than those with no ties, whereas funders with weak ties show no significant difference in information needs about the project creator compared to those without ties. We therefore conclude that relationship strength drives an increased need for information about the project team, in particular, for reward and financial (debt and equity) crowdfunding.

Second, only for donation crowdfunding do we find evidence that out-crowd funders rely more on 
Table 1 Results for all types of crowdfunding

\begin{tabular}{|c|c|c|c|c|c|c|}
\hline Variables & $\begin{array}{l}\text { (1) } \\
\text { Infoprojobj }\end{array}$ & $\begin{array}{l}\text { (2) } \\
\text { Infopersprev }\end{array}$ & $\begin{array}{l}\text { (3) } \\
\text { Infofinrisk }\end{array}$ & $\begin{array}{l}\text { (4) } \\
\text { Infoprojobj }\end{array}$ & $\begin{array}{l}\text { (5) } \\
\text { Infopersprev }\end{array}$ & $\begin{array}{l}\text { (6) } \\
\text { Infofinrisk }\end{array}$ \\
\hline Strongties & $\begin{array}{c}0.134 \\
(0.347)\end{array}$ & $\begin{array}{c}1.185 * * * \\
(0.331)\end{array}$ & $\begin{array}{c}0.101 \\
(0.330)\end{array}$ & & & \\
\hline Weakties & $\begin{array}{l}-0.377 \\
(0.258)\end{array}$ & $\begin{array}{c}0.903 * * * \\
(0.247)\end{array}$ & $\begin{array}{c}0.196 \\
(0.244)\end{array}$ & & & \\
\hline Noties & & & & $\begin{array}{c}0.308 \\
(0.247)\end{array}$ & $\begin{array}{c}-0.940 * * * \\
(0.235)\end{array}$ & $\begin{array}{l}-0.176 \\
(0.233)\end{array}$ \\
\hline Keepinmindrisk & $\begin{array}{c}0.110 \\
(0.101)\end{array}$ & $\begin{array}{c}0.120 \\
(0.0994)\end{array}$ & $\begin{array}{c}-0.0404 \\
(0.100)\end{array}$ & $\begin{array}{c}0.118 \\
(0.101)\end{array}$ & $\begin{array}{c}0.127 \\
(0.0993)\end{array}$ & $\begin{array}{l}-0.0418 \\
(0.0999)\end{array}$ \\
\hline Knowingfincontriboth & $\begin{array}{c}0.108 \\
(0.111)\end{array}$ & $\begin{array}{l}0.0287 \\
(0.109)\end{array}$ & $\begin{array}{c}0.384 * * * \\
(0.108)\end{array}$ & $\begin{array}{c}0.117 \\
(0.111)\end{array}$ & $\begin{array}{l}0.0365 \\
(0.109)\end{array}$ & $\begin{array}{c}0.383 * * * \\
(0.108)\end{array}$ \\
\hline Profit & $\begin{array}{c}-0.654 * \\
(0.346)\end{array}$ & $\begin{array}{l}-0.143 \\
(0.330)\end{array}$ & $\begin{array}{l}-0.430 \\
(0.333)\end{array}$ & $\begin{array}{c}-0.659 * \\
(0.346)\end{array}$ & $\begin{array}{l}-0.179 \\
(0.331)\end{array}$ & $\begin{array}{l}-0.439 \\
(0.332)\end{array}$ \\
\hline Social & $\begin{array}{c}0.452 \\
(0.307)\end{array}$ & $\begin{array}{l}0.0647 \\
(0.290)\end{array}$ & $\begin{array}{l}-0.396 \\
(0.295)\end{array}$ & $\begin{array}{c}0.505 \\
(0.308)\end{array}$ & $\begin{array}{l}0.0634 \\
(0.291)\end{array}$ & $\begin{array}{l}-0.409 \\
(0.295)\end{array}$ \\
\hline Cultural & $\begin{array}{c}0.124 \\
(0.381)\end{array}$ & $\begin{array}{l}-0.241 \\
(0.365)\end{array}$ & $\begin{array}{l}-0.570 \\
(0.369)\end{array}$ & $\begin{array}{c}0.227 \\
(0.378)\end{array}$ & $\begin{array}{l}-0.209 \\
(0.362)\end{array}$ & $\begin{array}{l}-0.593 \\
(0.367)\end{array}$ \\
\hline Ecological & $\begin{array}{c}0.825 * * * \\
(0.318)\end{array}$ & $\begin{array}{l}-0.386 \\
(0.299)\end{array}$ & $\begin{array}{c}0.141 \\
(0.303)\end{array}$ & $\begin{array}{c}0.838^{* * * *} \\
(0.317)\end{array}$ & $\begin{array}{l}-0.357 \\
(0.299)\end{array}$ & $\begin{array}{c}0.144 \\
(0.302)\end{array}$ \\
\hline Amount & $\begin{array}{l}-0.0261 \\
(0.0496)\end{array}$ & $\begin{array}{c}0.0160 \\
(0.0475)\end{array}$ & $\begin{array}{c}0.132 * * * \\
(0.0489)\end{array}$ & $\begin{array}{l}-0.0184 \\
(0.0494)\end{array}$ & $\begin{array}{c}0.0129 \\
(0.0476)\end{array}$ & $\begin{array}{c}0.131 * * * \\
(0.0490)\end{array}$ \\
\hline Gender & $\begin{array}{c}0.300 \\
(0.241)\end{array}$ & $\begin{array}{c}0.303 \\
(0.229)\end{array}$ & $\begin{array}{c}0.139 \\
(0.233)\end{array}$ & $\begin{array}{c}0.310 \\
(0.241)\end{array}$ & $\begin{array}{c}0.301 \\
(0.229)\end{array}$ & $\begin{array}{c}0.139 \\
(0.233)\end{array}$ \\
\hline Age & $\begin{array}{c}0.269 * * \\
(0.113)\end{array}$ & $\begin{array}{l}0.174 * \\
(0.105)\end{array}$ & $\begin{array}{l}0.177 * \\
(0.107)\end{array}$ & $\begin{array}{c}0.270 * * \\
(0.113)\end{array}$ & $\begin{array}{l}0.184 * \\
(0.105)\end{array}$ & $\begin{array}{c}0.175 \\
(0.107)\end{array}$ \\
\hline Education & $\begin{array}{c}0.0244 \\
(0.0709)\end{array}$ & $\begin{array}{c}-0.103 \\
(0.0685)\end{array}$ & $\begin{array}{l}-0.0202 \\
(0.0663)\end{array}$ & $\begin{array}{c}0.0169 \\
(0.0704)\end{array}$ & $\begin{array}{l}-0.0977 \\
(0.0684)\end{array}$ & $\begin{array}{l}-0.0193 \\
(0.0664)\end{array}$ \\
\hline Securityreturn & $\begin{array}{c}0.533 * * * \\
(0.117)\end{array}$ & $\begin{array}{c}0.506 * * * \\
(0.110)\end{array}$ & $\begin{array}{c}0.456^{* * *} \\
(0.109)\end{array}$ & $\begin{array}{c}0.510 * * * \\
(0.117)\end{array}$ & $\begin{array}{c}0.499 * * * \\
(0.109)\end{array}$ & $\begin{array}{c}0.458 * * * \\
(0.110)\end{array}$ \\
\hline Donation & $\begin{array}{c}0.149 \\
(0.295)\end{array}$ & $\begin{array}{c}0.809 * * * \\
(0.286)\end{array}$ & $\begin{array}{c}0.451 \\
(0.294)\end{array}$ & $\begin{array}{c}0.123 \\
(0.293)\end{array}$ & $\begin{array}{c}0.776 * * * \\
(0.285)\end{array}$ & $\begin{array}{c}0.447 \\
(0.293)\end{array}$ \\
\hline Financial return & $\begin{array}{c}0.260 \\
(0.344)\end{array}$ & $\begin{array}{l}0.584 * \\
(0.313)\end{array}$ & $\begin{array}{c}0.878 * * * \\
(0.317)\end{array}$ & $\begin{array}{c}0.225 \\
(0.343)\end{array}$ & $\begin{array}{l}0.557 * \\
(0.313)\end{array}$ & $\begin{array}{c}0.884 * * * \\
(0.316)\end{array}$ \\
\hline Observations & 287 & 287 & 283 & 287 & 287 & 283 \\
\hline Pseudo R2 & 0.0633 & 0.0536 & 0.0599 & 0.0607 & 0.0519 & 0.0598 \\
\hline LR Chi2 & 53.59 & 57.29 & 67.01 & 51.38 & 55.47 & 66.93 \\
\hline Prob $<$ Chi 2 & $3.07 \mathrm{e}-06$ & $7.33 \mathrm{e}-07$ & $1.51 \mathrm{e}^{-}-08$ & $3.58 \mathrm{e}-06$ & $7.19 \mathrm{e}^{-07}$ & $6.90 \mathrm{e}^{-}-09$ \\
\hline
\end{tabular}

Standard errors in parentheses

$* * * p<0.01, * * p<0.05, * p<0.1$

information about the project and its objectives compared to in-crowd funders (an effect in line with hypothesis 2). This is driven by the significantly lower need for information about the project and its objectives in donation crowdfunding by funders with weak ties, who rely less on this information than those with strong ties or no ties (a U-shaped relationship between project information need and the strength of ties). 
Overall, and for reward and financial return crowdfunding individually, we find no evidence that out-crowd funders rely more on information about the project than in-crowd funders. We therefore reject our second hypothesis (H2) both for our aggregated model and for reward and financial return crowdfunding; a higher information need about the project and its objectives only holds for those funders with no ties participating in donation crowdfunding in relation to funders with weak ties in donation crowdfunding.

Third, we find evidence that in financial return crowdfunding, out-crowd funders rely more on information about financial planning and risk than in-crowd funders. This result is driven mostly by funders with strong ties, who indicate a significantly lower information need for financial planning and risk than funders with no ties. This decreased information need is not observed for funders with weak ties. For donation and reward crowdfunding, and in our model that includes all types of crowdfunding, we find no significant differences in information needs about financial planning and risks for any strength of ties. Hence, our hypothesis 3 (H3) is supported for financial return (debt and equity) crowdfunding and rejected for reward and donation crowdfunding.

\subsection{Types of crowdfunding projects}

We also investigated the influence of different types of projects on the use of information about the project, entrepreneur and financial planning and risks by funders with different strength of ties. We carried out this analysis by adding project-type dummies to the full model (profit, social, ecological and cultural). First, we find no influence of project type on the information need about the project owner. Second, we find that the importance of information about the project and its objectives varies with the project type. In for-profit campaigns, funders attach less importance to information about the project and its objectives. In campaigns with an ecological purpose, this effect is reversed. These effects are consistent across all relationship types. In donation-based and reward-based crowdfunding, the coefficients for both for-profit and ecological projects are higher. The importance of information about the project and its objectives is high in donation-based crowdfunding for ecological projects. Also, in the presence of strong ties, the negative coefficient for for-profit projects disappears. Third, the importance of information about finance and risks does not vary with the type of project in our full model that includes all crowdfunding types. Interestingly, within reward-based crowdfunding (our largest subset), funders of cultural and for-profit projects attach less importance to information about finance and risks than those funding social and ecological projects. This could indicate that these projects display higher informational asymmetries related to their social and ecological goals versus cultural and for-profit projects. Financial return crowdfunding exhibits no significantly different information use based on the type of project, except for a decreased information use about the owner and her track record.

\subsection{Control variables}

As for our control variables, age and security of a promised return (which we interpret as instrumental motivation) show a statistically significant positive relationship to nearly all information variables in our full model. Age is only insignificant for information needs about finance and risk. When we split up the data into different types of crowdfunding, age loses most of its significance. The positive significant relationship between instrumental motivation and information needs remains consistent in all types of crowdfunding, except for information about finance and risks in financial return crowdfunding. This is probably due to lack of variation within this category (financial return funders are likely to be instrumentally motivated). We find a strong positive moderating relationship for donation- and financial return crowdfunding regarding information about the entrepreneur and track-record as well as information about financials and risk in financial return crowdfunding. As expected, the size of the investment (amount) drives the importance of information about financial planning and risks. Risk awareness is not significantly correlated with the importance of information in general. Knowing the financial contribution of others increases the importance of information about financial planning and risks, indicating some additionality between knowing the contribution of others and information gathering for particularly out-crowd, instrumentally motivated fundersthe contribution of others increases the chance that the project will be fully funded and therefore increases the expected payoff of time taken to gather financial and risk information. 


\subsection{Robustness checks}

In order to check the robustness of our findings, we checked for multi-collinearity i.e. the correlation amongst explanatory variables. Investigating the variance inflation factors (VIFs) reveals no multicollinearity, given the mean VIF of 1.5 in models including all types of crowdfunding and 1.6, 1.5, 1.7 in models using donation-based, reward-based and financial return crowdfunding respectively (see Kutner et al. 2005). We also divided relationship-dependent variables into in-crowd and out-crowd and calculated the models again. The results remained consistent. As a robustness check for the dependent variables (importance of information), we included measures that incorporate these types of information (quality of the project, reasons for the existence of the project, information about the project/objectives, knowledge and skills of the project creator and their passion, information about the person/ track record). Strong and weak ties positively influence the importance of the knowledge and skills of the entrepreneur and thus confirm our main results. In the case of no ties to the project, this coefficient becomes negative, which is also consistent with our results. As an alternative measure of our relationship strength variable, we included the self-reported importance of the relationship for the funding decision. A higher value drives the information about the entrepreneur and previous projects, consistent with our main results.

\section{Discussion}

The guiding research question was 'how does the type of information used by crowdfunders vary with the strength of their ties to project creators?' Overcoming information asymmetries, prevalent in the relationship between financier and entrepreneur, especially for young and innovative firms, has traditionally been a role of venture capitalists that screen, select and monitor potential targets and syndicate with other investors through social networks to pool resources, exchange information and spread the risks (Alexy et al. 2012; Gompers and Lerner 2001; Manigart and Wright 2011; Shane and Cable 2002; Ter Wal et al. 2016). Our research adds to the informal investor and crowdfunding literature on overcoming information asymmetries in social networks by disentangling quality signals used by crowdfunders to judge project quality (Audretsch et al. 2012; Becker-Blease and Sohl 2015).

5.1 Information heterogeneity and social networks of crowdfunders

First, researchers stressed the role of internal social capital (early backers) as signals for funding success (Ahlers et al. 2015; Colombo et al. 2015; Cumming et al. 2015a; Vismara 2016a, 2016b). We add to this line of research by differentiating types of information required by potential investors, based on their relationship with the project creator. Whereas in-crowd funders rely on information about the person behind the campaign and previous projects, there is no increased use of information about financials and associated risks. These results are in line with previous research on crowdfunding motivation (Cholakova and Clarysse 2015). Our results show that in-crowd funders are not just involved out of sympathy or relationship building (we control for instrumental motivation) but also search for information that signals project quality or behavioural intentions thereby complementing earlier work that found a positive relationship between strength of ties and altruistic investment behaviour (Klyver et al. 2016). The inclusion of the entrepreneurs' social network informs the funding decision in a similar way to the VCentrepreneur relationship (Huang and Knight 2015; Manigart and Wright 2011; Shane and Cable 2002).

We extend previous work on the 'wisdom of the crowd' in collective funding decisions (Mollick and Nanda 2015; Surowiecki 2005) with regards to the use of information about the project and the project creator. Our research confirms the notion that relationships between investors and project creators facilitate the exchange of information about the entrepreneur and their track record, a mechanism prevalent in $\mathrm{VC} /$ angel investor-relationships (Bernstein et al. 2016b; Vismara 2016a). Our findings suggest that the in-crowd gathers (soft) information about the management of the venture (Ahlers et al. 2015; Cholakova and Clarysse 2015; Cumming et al. 2015a).

Second, we find no consistent evidence for our hypothesis that out-crowd funders rely more on information about the project and its objectives in decision making than in-crowd funders. This in contrast to predictions from previous studies (Ahlers et al. 2015; Hornuf and Schwienbacher 2015). Even though they do rely significantly less on information about the 
person than in-crowd investors, this is not being compensated by a greater reliance on information about the project. It raises concerns with regard to the quality of decision making of out-crowd funders contrary to findings in previous studies (Mollick and Nanda 2015).

Third, we hypothesised that out-crowd funders investigate information about financial planning and risk more thoroughly to search for quality signals and commitment (Ahlers et al. 2015; Blumberg and Letterie 2007; Busenitz et al. 2005; Hornuf and Schwienbacher 2015). We find that this hypothesis holds for financial crowdfunding. In our full model, we find no support for this notion and also find that funders in general - with or without ties - attach a lower importance to this type of information.

Crowdfunding decision making can thus be characterised as relationship-driven (Bernstein et al. 2016b; Colombo et al. 2015). In this regard, crowdfunders, when aggregated across all types, apparently behave differently to professional (VC) investors who rely also on financial due diligence and an alignment of goals between venture and investor (Audretsch et al. 2012; Bernstein et al. 2016b; Busenitz et al. 2005). This study also reveals interesting differences regarding the use of information of distinct types of campaigns, which adds to the understanding of funding dynamics (Belleflamme et al. 2014; Calic and Mosakowski 2016; Hornuf and Schwienbacher 2015; Mollick 2014). Forprofit project funders are significantly less interested in information about the projects and its objectives than others, particularly compared to ecological project funders who attach a significantly higher importance to the objective of a project. This could be explained by either warm-glow or impact motivations (Andreoni 1990; Maas and Liket 2010). These effects are strongest in donation-based crowdfunding. Our findings corroborate recent studies on crowdfunding social and environmental enterprises and projects reporting mixed evidence of funding success to sustainability orientation and goals (Calic and Mosakowski 2016; Hörisch 2015).

\subsection{Information heterogeneity across types of crowdfunding}

We find more support for our hypotheses when we separate distinct types of crowdfunding. The mechanisms through which we expect social networks to affect informational needs (motivation, intention of the project owner and quality of the project) seem to lead to different information needs for donation, reward, and financial (debt and equity) crowdfunding decisions. Donation-based crowdfunding is often associated with non-financial motivations and non-profit organisations, whereas reward-based and financial crowdfunding are more commonly associated with for-profit or social entrepreneurs and financial motivation (Ahlers et al. 2015; Cholakova and Clarysse 2015; Mollick and Nanda 2015). In financial - debt or equity crowdfunding, return for funders depends on the ability of the venture to generate enough profit to pay back a loan (debt) or create an exit scenario (equity). These crowdfunders rank the support to family, friends or local business very low as a motivation to invest (Nesta 2014; Vismara 2016b). Others distinguish between equity and reward-based crowdfunding and find that both are driven by financial motives, whether in-kind or financial (Cholakova and Clarysse 2015).

Before accounting for relationship strength, we find significant differences in information needs between crowdfunding types. In general, financial return (debt and equity) funders have higher information needs about the entrepreneur than reward funders. This is in line with VC literature predictions (Alexy et al. 2012; Bernstein et al. 2016b; Busenitz et al. 2005; Shane and Cable 2002) as well as Ahlers et al. (2015) who indicate that financial return crowdfunding leads to higher concerns of moral hazard and a greater need for quality signals compared to reward and donation crowdfunding due to the long-term commitment to the enterprise, higher risk and expected returns. Low fears of moral hazard and a focus on product information render all types of reward crowdfunders less interested in information about the project owner.

Our granular models, in which we account for the effect of relationship strength per type of crowdfunding, show that in both reward and financial return crowdfunding, in-crowd funders have a significantly higher information need about the person behind the project than out-crowd funders. This suggests that even at the lower level of informational need within rewardbased crowdfunding, relationship strength plays a role, thus adding a novel insight to the literature on the role of social networks in crowdfunding.

Interestingly, donation-based funders show significantly higher levels of information need about the person behind the project than reward-based funders, at similar levels as financial return crowdfunding. This is counter to expectations of Belleflamme et al. (2014) and 
Ahlers (2015), who argue that in donation-based crowdfunding the degree of asymmetric information is of little importance because other intangible factors increase the funders' utility. We explain this from a motivation perspective. Donation crowdfunding can be likened to philanthropy, where 'returns' can be in the form of 'warm glow' (Andreoni 1990), societal impact (Maas and Liket 2010) or community benefits (Belleflamme et al. 2014). Donation funders interested in the (social, cultural or ecological) impact of their donation are more likely to be motivated to look for quality signals, indicating that their money will be well spent, before pledging their funds.

When we look at the effect of strength of ties on information needs in donation-based crowdfunding, we find no increased demand for information on either the project creator or financial planning and risks. However, for out-crowd donation-based crowdfunding, we find a significantly higher information need about the project and its objectives than for in-crowd funders. This is driven by a negative effect of weak ties in particular. This lower interest of weak tie funders in information about the project may point to a (weak) relationship motivation to donate instead of interest in the project and its impact. This is in contrast to, on the one hand, strong tie funders who may display interest in the project due to their strong relationship and, on the other hand, due to out-crowd funders who donate primarily out of interest in the project, without a social relationship.

We also find that compared to reward-based and donation crowdfunding, financial return funders, with and without ties, are significantly more interested in information about financial planning and risks. The risk profile of reward-based crowdfunding is lower than debt or equity crowdfunding since they can be seen as early adopting consumers (Hornuf and Schwienbacher 2015; Vismara 2016a) and their return does not depend on the long-term profitability of the enterprise, only on the ability to deliver the promised product. Non-delivery rates on the largest reward-based platform Kickstarter are approximately 9\% (Mollick 2015), which points to a much lower risk than average venture failure rates (Aldrich and Ruef 2006). Within the subset of financial return crowdfunding, we find that out-crowd funders have a higher need for information about finance and risk than in-crowd funders. Our results indicate that a strong relationship appears to substitute financial due diligence and complements the importance of teams quality signals as financial return funders with strong ties are less interested in information about finance and risk (Ahlers et al. 2015; Bernstein et al. 2016b; Uzzi 1999).

\section{Conclusions and implications}

\subsection{Conclusions}

Our study offers the first detailed analysis of the heterogeneity in information use by crowdfunders and more particular how information use is affected by social networks within different types of crowdfunding.

This paper highlights the heterogeneity in information use by crowdfunders that are differently connected to the project creator. Funders from the incrowd attach more importance to information about the project creator, as expected, but funders from the out-crowd do not rely more on information about the project, except for donation-based crowdfunding. Our findings suggest a trade-off between strong ties and the importance of information about financial planning and risks in the context of financial return (equity and debt) crowdfunding. In general, this information is perceived as less important and is not influenced by social network ties between crowdfunder and project for donation and reward crowdfunding. Donation and financial return crowdfunders attach more importance to the information about the person behind the project which reflects a relationship-based funding approach, whereas reward-based crowdfunders care significantly less about the project creator as they focus on the product as specific output with lower information asymmetry issues. Additionally, the information use of crowdfunders is influenced by the type of project they invest in. For-profit project funders need less information about a project and its objectives whereas ecological projects exhibit a higher need for this type of information.

\subsection{Implications}

Our research has important implications for project developers and platform managers. Based on the results of our research, platform managers and project owners can customise their campaign directly to the group of 
Fig. 2 Information use heterogeneity of crowdfunders with different strength of ties to project creator

\begin{tabular}{|c|c|c|c|}
\hline $\begin{array}{l}\text { Information } \\
\text { use regarding: }\end{array}$ & Project \& objectives & $\begin{array}{l}\text { Person \& previous } \\
\text { projects }\end{array}$ & $\begin{array}{l}\text { Financial } \\
\text { planning \& risks }\end{array}$ \\
\hline Strong ties & Average (all) & $\begin{array}{c}\text { High (all) } \\
\text { Average (donation) }\end{array}$ & $\begin{array}{c}\text { Average (all) } \\
\text { Low (financial) }\end{array}$ \\
\hline Weak ties & $\begin{array}{c}\text { Average (all) } \\
\text { Low (donation) }\end{array}$ & $\begin{array}{c}\text { High (all) } \\
\text { Average (financial) }\end{array}$ & Average (all) \\
\hline No ties & $\begin{array}{c}\text { Average (all) } \\
\text { High (donation) }\end{array}$ & $\begin{array}{c}\text { Low (all) } \\
\text { Average (donation) }\end{array}$ & Average (all) \\
\hline
\end{tabular}

funders they would like to attract, based on their relationship strength and also on insights from our control variables (age, gender, education, instrumental motivation or financial means). More importantly, it is possible to deploy a tailored and staged in-crowd/out-crowd process of crowdfunding (see Fig. 2). We indicate 'average' information use when coefficients are small or not significant.

Project creators can focus on providing detailed information about themselves and their previous projects to potential in-crowd funders (strong and weak ties) and display more summarised information about the project, its objectives, financial planning and risks. For potential out-crowd funders, the campaign should instead focus on information about the project and its objectives (especially for donation-based campaigns) and financial planning/risks (for financial return crowdfunding) and summarise personal information about the project creator.

\subsection{Limitations and future research}

Although this research provides new empirical evidence on decision making by crowdfunders, there are some limitations to our study and interesting pathways for further research. Limitations arise firstly from the use of the survey instrument, where we cannot control for non-response or socialdesirability bias. Secondly, as the sampling followed a snowball method, the composition of groups (age, gender, education, experience with crowdfunding) does not necessarily represent the general population of crowdfunders. Our sub-samples within crowdfunding types are relatively small (50-160 respondents) which limits the statistical power of our analyses. Third, our dataset was collected in 2013, a time at which crowdfunding was emergent. More recent datasets will probably provide different insights as the phenomenon of crowdfunding has become more widespread, in particular equity crowdfunding. Broader samples could give more insights into the motivations and behaviour of crowdfunders, including barriers to crowdfunding. A weakness of the survey itself is that we cannot compare the use of information by funders with the use of information of those that decided not to fund, since this question was only asked to the funders. Finally, we cannot distinguish between early- and late-stage funders, as information about investment timing is missing.

To further this research, a combination of field experiment and real-time data from platforms where we could observe the relationship between use of information, strength of ties and commitment of others during the funding decision in real life would provide more insight into the causality of the relations found in this study. Combining project-level investment data with survey data about the funders would elicit a clearer and more robust picture of funding decisions (Jick 1979) and eliminate potential common method bias (Podsakoff et al. 2003). Finally, it would be valuable to explore other institutional contexts outside of the Netherlands, with differently developed financial markets (including angel investing and venture capital), levels of entrepreneurship, and regulation of financial markets and crowdfunding in particular.

Acknowledgements The authors are grateful for the time and support of the survey participants and the organizers of the National Crowdfunding Onderzoek 2013: Peter van den Akker, Ronald Kleverlaan, Gijsbert Koren en Koen van Vliet. Jeroen de Jong and the team of the Chair of Strategy, Organization and Entrepreneurship at the Utrecht University School of Economics, Harry Commandeur and Karen Maas (Erasmus University Rotterdam), Shinjinee Chattopadhyay (University of Illinois at UrbanaChampaign), Jeffrey Kuhn (EPFL), as well as two anonymous conference reviewers and two anonymous journal reviewers provided valuable comments on earlier versions of the paper. The opportunity to present and discuss this research at DRUID Anniversary Summer Conference 2016 and G-Forum Entrepreneurship Conference 2016 helped us tremendously in further refining our argument. Amar Bhidé provided valuable input during the emergence of this research project. 


\section{Appendix}

Descriptive statistics

Table 2 Number of cases, means, standard deviations

\begin{tabular}{|c|c|c|c|c|c|c|}
\hline Variable & Obs & Mean & Std Dev & Min & Max & Variable description \\
\hline Infoprojobj & 283 & 4.30212 & 0.7887029 & 1 & 5 & $\begin{array}{l}\text { Likert scale (1-5) average of importance of information about (1) the } \\
\text { project or company and (2) objectives of project or company }\end{array}$ \\
\hline Infopersprev & 281 & 3.706406 & 0.9004532 & 1 & 5 & $\begin{array}{l}\text { Likert scale (1-5) average of importance of information about (1) the } \\
\text { person or organization behind the project or the company and (2) } \\
\text { previous projects of the person or organization behind it }\end{array}$ \\
\hline Infofinrisk & 283 & 3.30742 & 1.016276 & 1 & 5 & $\begin{array}{l}\text { Likert scale (1-5) average of importance of information about (1) } \\
\text { financial planning of the project or company and (2) risks associated } \\
\text { with the project or the company }\end{array}$ \\
\hline Strongties & 283 & 0.180212 & 0.3850448 & 0 & 1 & Dummy: 1 is strong ties (family, friend, initiator/employee) \\
\hline Weakties & 283 & 0.4770318 & 0.500357 & 0 & 1 & $\begin{array}{l}\text { Dummy: } 1 \text { is weak ties (I know the person, friend of friend, business } \\
\text { relationship) }\end{array}$ \\
\hline Noties & 283 & 0.3427562 & 0.4754716 & 0 & 1 & Dummy: 1 is no ties (There is no relationship) \\
\hline Knowingfincontriboth & 283 & 2.501767 & 1.063163 & 1 & 5 & $\begin{array}{l}\text { Likert scale 1-5: How important is knowing the financial contribution } \\
\text { by others }\end{array}$ \\
\hline Keepinmindrisk & 283 & 3.667845 & 1.227315 & 1 & 5 & $\begin{array}{l}\text { Likert scale }(1-5) \text { : I keep in mind the consideration that investing } \\
\text { through crowdfunding in an company can be a high risk investment }\end{array}$ \\
\hline Profit & 283 & 0.3674912 & 0.4829758 & 0 & 1 & Dummy. Type of project invested in. 1 = for-profit, 0 other. \\
\hline Social & 283 & 0.4416961 & 0.4974687 & 0 & 1 & Dummy. Type of project invested in. $1=$ social, 0 other \\
\hline Cultural & 283 & 0.3250883 & 0.4692376 & 0 & 1 & Dummy. Type of project invested in. $1=$ cultural, 0 other \\
\hline Ecological & 283 & 0.2438163 & 0.4301438 & 0 & 1 & Dummy. Type of project invested in. $1=$ ecological, 0 other \\
\hline Amount & 283 & 5.190813 & 2.519214 & 1 & 11 & $\begin{array}{l}\text { Scale }(1-11) \text { : less than } € 10 / € 11-€ 25 / € 26-€ 50 / € 51-€ 100 / € 101-€ \\
250 / € 251-€ 500 / \text { more than } € 500\end{array}$ \\
\hline Gender & 283 & 1.388693 & 0.4883168 & 1 & 2 & Dummy male $=1 ;$ female $=2$ \\
\hline Age & 283 & 4.035336 & 1.057977 & 1 & 7 & $\begin{array}{l}\text { Scale (1-7): under } 18 \text { years } / 18-24 \text { year/25-34 years/35-44 years } / 45- \\
54 \text { years/55-64 years/over } 65 \text { years }\end{array}$ \\
\hline Education & 283 & 8.007067 & 1.584484 & 1 & 10 & $\begin{array}{l}\text { Scale (1-10): lower education or primary edn/lower vocational edn/ } \\
\text { high school or VMBO/HAVO/VWO/MBO/HBO/univ bachelor/ } \\
\text { univ master's or doctoral/post-doc }\end{array}$ \\
\hline Securityreturn & 283 & 3.60424 & 1.08777 & 1 & 5 & Importance of the security that there is a promised return \\
\hline Donation & 283 & 0.254417 & 0.4363045 & 0 & 1 & $\begin{array}{l}\text { Dummy: What type of financial return have you received or will you } \\
\text { receive in exchange for your financial contribution? Answer: no } \\
\text { reward }\end{array}$ \\
\hline Reward & 283 & 0.5759717 & 0.49507 & 0 & 1 & $\begin{array}{l}\text { Dummy: What type of financial return have you received or will you } \\
\text { receive in exchange for your financial contribution? Answer: reward } \\
\text { (e.g. a product, service or mention your name) }\end{array}$ \\
\hline Financialreturn & 283 & 0.1696113 & 0.3759558 & 0 & 1 & $\begin{array}{l}\text { Dummy: What type of financial return have you received or will you } \\
\text { receive in exchange for your financial contribution? Answer: a } \\
\text { financial return (e.g. in the case of a loan or investment) }\end{array}$ \\
\hline
\end{tabular}




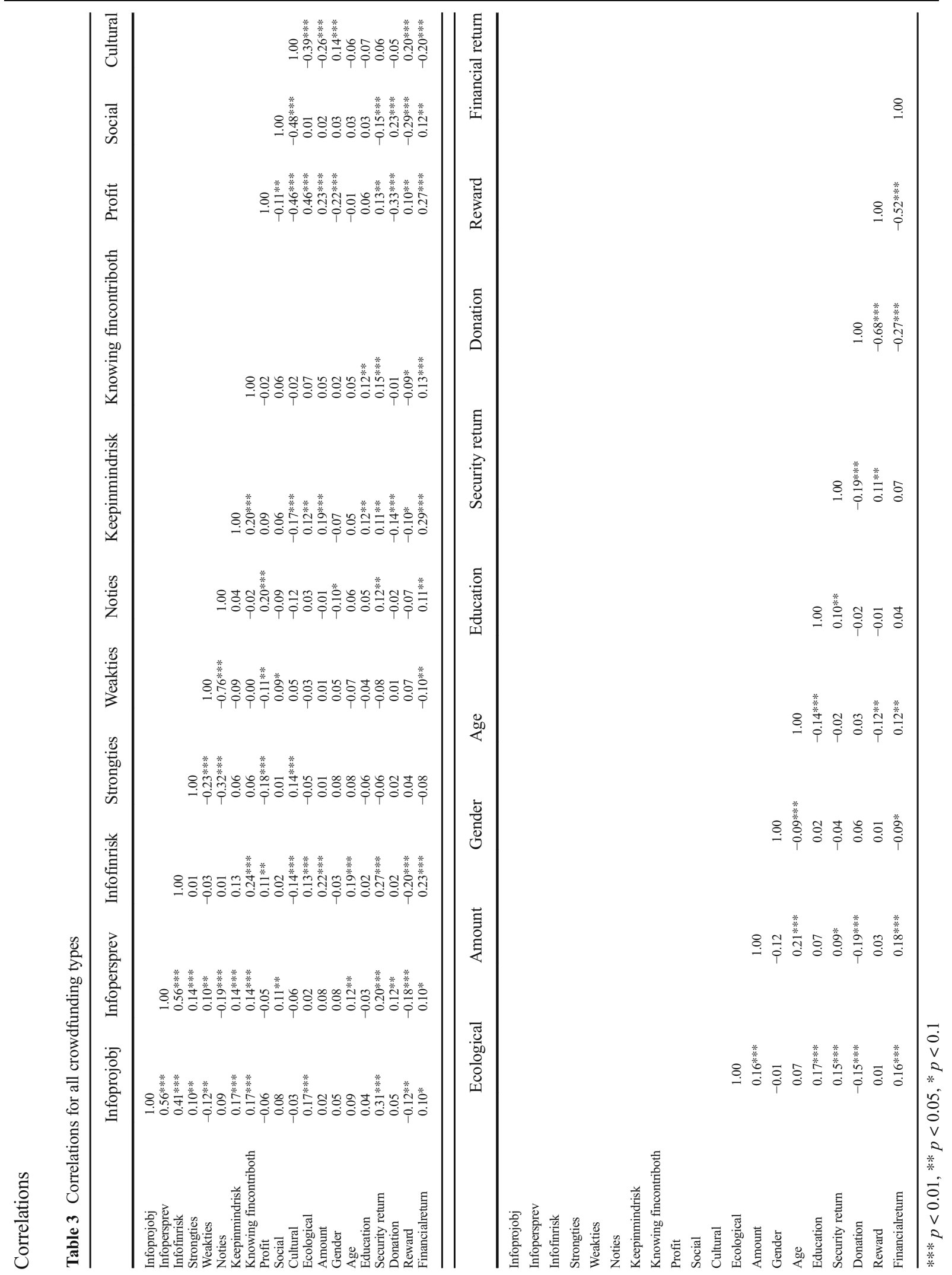


Differentiated analyses

Table 4 Results for donation-based crowdfunding

\begin{tabular}{|c|c|c|c|c|c|c|}
\hline Variables & Infoprojobj & Infopersprev & Infofinrisk & Infoprojobj & Infopersprev & Infofinrisk \\
\hline \multirow[t]{2}{*}{ Strongties } & -0.719 & 1.063 & 0.315 & & & \\
\hline & $(0.760)$ & $(0.709)$ & $(0.673)$ & & & \\
\hline \multirow[t]{2}{*}{ Weakties } & $-1.048 *$ & 0.155 & 0.350 & & & \\
\hline & $(0.556)$ & $(0.495)$ & $(0.525)$ & & & \\
\hline \multirow[t]{2}{*}{ Noties } & & & & $0.976^{*}$ & -0.374 & -0.340 \\
\hline & & & & $(0.534)$ & $(0.468)$ & $(0.489)$ \\
\hline \multirow[t]{2}{*}{ Keepinmindrisk } & -0.0788 & 0.207 & -0.235 & -0.0824 & 0.196 & -0.234 \\
\hline & $(0.201)$ & $(0.182)$ & $(0.189)$ & $(0.200)$ & $(0.181)$ & $(0.189)$ \\
\hline \multirow[t]{2}{*}{ Knowingfincontriboth } & $-0.422 *$ & 0.00908 & 0.0197 & $-0.412 *$ & 0.0294 & 0.0198 \\
\hline & $(0.237)$ & $(0.240)$ & $(0.227)$ & $(0.236)$ & $(0.242)$ & $(0.227)$ \\
\hline \multirow[t]{2}{*}{ Profit } & $-1.602 *$ & -1.057 & 0.205 & $-1.619 *$ & -1.129 & 0.208 \\
\hline & $(0.950)$ & $(0.913)$ & $(1.040)$ & $(0.948)$ & $(0.911)$ & $(1.038)$ \\
\hline \multirow[t]{2}{*}{ Social } & 1.179 & -0.415 & -0.926 & 1.197 & -0.391 & -0.929 \\
\hline & $(0.837)$ & $(0.793)$ & $(0.862)$ & $(0.838)$ & $(0.802)$ & $(0.860)$ \\
\hline \multirow[t]{2}{*}{ Cultural } & 1.159 & -0.903 & -0.940 & 1.252 & -0.695 & -0.947 \\
\hline & $(0.928)$ & $(0.867)$ & $(0.917)$ & $(0.910)$ & $(0.863)$ & $(0.909)$ \\
\hline \multirow[t]{2}{*}{ Ecological } & $1.866^{* *}$ & 0.526 & -0.801 & $1.895 * *$ & 0.562 & -0.800 \\
\hline & $(0.853)$ & $(0.831)$ & $(0.899)$ & $(0.848)$ & $(0.827)$ & $(0.899)$ \\
\hline \multirow[t]{2}{*}{ Amount } & 0.0637 & 0.0947 & 0.125 & 0.0635 & 0.0951 & 0.126 \\
\hline & $(0.103)$ & $(0.101)$ & (0.0999) & $(0.103)$ & $(0.102)$ & $(0.0987)$ \\
\hline \multirow[t]{2}{*}{ Gender } & 0.298 & 0.766 & 0.636 & 0.292 & 0.742 & 0.635 \\
\hline & $(0.498)$ & $(0.486)$ & $(0.468)$ & $(0.497)$ & $(0.484)$ & $(0.467)$ \\
\hline \multirow[t]{2}{*}{ Age } & 0.185 & -0.132 & 0.327 & 0.207 & -0.0993 & 0.324 \\
\hline & $(0.235)$ & $(0.216)$ & $(0.226)$ & $(0.230)$ & $(0.214)$ & $(0.220)$ \\
\hline \multirow[t]{2}{*}{ Education } & -0.0767 & -0.211 & 0.0676 & -0.0893 & -0.250 & 0.0692 \\
\hline & $(0.163)$ & $(0.157)$ & $(0.143)$ & $(0.161)$ & $(0.156)$ & $(0.139)$ \\
\hline \multirow[t]{2}{*}{ Securityreturn } & $0.621 * * *$ & $0.691 * * *$ & $0.759 * * *$ & $0.617 * * *$ & $0.675 * * *$ & $0.758 * * *$ \\
\hline & $(0.224)$ & $(0.206)$ & $(0.220)$ & $(0.224)$ & $(0.204)$ & $(0.220)$ \\
\hline Observations & 74 & 74 & 72 & 74 & 74 & 72 \\
\hline Pseudo R2 & 0.101 & 0.0925 & 0.0863 & 0.100 & 0.0858 & 0.0863 \\
\hline LR Chi2 & 21.12 & 24.64 & 24.38 & 20.90 & 22.86 & 24.38 \\
\hline Prob < Chi 2 & 0.0705 & 0.0257 & 0.0278 & 0.0519 & 0.0289 & 0.0180 \\
\hline
\end{tabular}

Standard errors in parentheses

*** $p<0.01, * * p<0.05, * p<0.1$ 
Table 5 Results for reward-based crowdfunding

\begin{tabular}{|c|c|c|c|c|c|c|}
\hline Variables & Infoprojobj & Infopersprev & Infofinrisk & Infoprojobj & Infopersprev & Infofinrisk \\
\hline \multirow[t]{2}{*}{ Strongties } & 0.316 & $1.013 * *$ & -0.0798 & & & \\
\hline & $(0.457)$ & $(0.427)$ & $(0.439)$ & & & \\
\hline \multirow[t]{2}{*}{ Weakties } & -0.354 & $1.194 * * *$ & 0.0959 & & & \\
\hline & $(0.352)$ & $(0.337)$ & $(0.330)$ & & & \\
\hline \multirow[t]{2}{*}{ Noties } & & & & 0.198 & $-1.145 * * *$ & -0.0562 \\
\hline & & & & $(0.339)$ & $(0.320)$ & $(0.318)$ \\
\hline \multirow[t]{2}{*}{ Keepinmindrisk } & $0.262 *$ & 0.187 & -0.0310 & $0.282 * *$ & 0.181 & -0.0361 \\
\hline & $(0.136)$ & $(0.133)$ & $(0.130)$ & $(0.135)$ & $(0.132)$ & $(0.129)$ \\
\hline \multirow[t]{2}{*}{ Knowingfincontriboth } & 0.225 & -0.0781 & $0.501 * * *$ & 0.230 & -0.0760 & $0.503 * * *$ \\
\hline & $(0.157)$ & $(0.150)$ & $(0.148)$ & $(0.157)$ & $(0.150)$ & $(0.148)$ \\
\hline \multirow[t]{2}{*}{ Profit } & $-0.769 *$ & -0.314 & $-0.764 *$ & $-0.807 *$ & -0.311 & $-0.758 *$ \\
\hline & $(0.463)$ & $(0.436)$ & $(0.457)$ & $(0.461)$ & $(0.435)$ & $(0.456)$ \\
\hline \multirow[t]{2}{*}{ Social } & 0.329 & 0.193 & -0.362 & 0.403 & 0.173 & -0.386 \\
\hline & $(0.402)$ & $(0.377)$ & $(0.383)$ & $(0.401)$ & $(0.373)$ & $(0.378)$ \\
\hline \multirow[t]{2}{*}{ Cultural } & 0.0381 & -0.241 & $-0.831^{*}$ & 0.0889 & -0.261 & $-0.854 *$ \\
\hline & $(0.495)$ & $(0.466)$ & $(0.481)$ & $(0.491)$ & $(0.464)$ & $(0.478)$ \\
\hline \multirow[t]{2}{*}{ Ecological } & $1.022 * *$ & -0.408 & 0.252 & $0.947 * *$ & -0.391 & 0.272 \\
\hline & $(0.432)$ & $(0.403)$ & $(0.406)$ & $(0.429)$ & $(0.400)$ & $(0.403)$ \\
\hline \multirow[t]{2}{*}{ Amount } & 0.00523 & 0.0277 & $0.116^{*}$ & 0.0182 & 0.0264 & 0.112 \\
\hline & $(0.0688)$ & $(0.0666)$ & $(0.0695)$ & $(0.0684)$ & $(0.0664)$ & $(0.0689)$ \\
\hline \multirow[t]{2}{*}{ Gender } & 0.329 & 0.135 & 0.106 & 0.346 & 0.135 & 0.107 \\
\hline & $(0.322)$ & $(0.307)$ & $(0.316)$ & $(0.321)$ & $(0.308)$ & $(0.317)$ \\
\hline \multirow[t]{2}{*}{ Age } & 0.217 & 0.178 & 0.194 & 0.209 & 0.177 & 0.191 \\
\hline & $(0.155)$ & $(0.145)$ & $(0.149)$ & $(0.155)$ & $(0.145)$ & $(0.148)$ \\
\hline \multirow[t]{2}{*}{ Education } & 0.0653 & -0.0850 & -0.00993 & 0.0677 & -0.0889 & -0.0146 \\
\hline & $(0.0897)$ & $(0.0895)$ & $(0.0876)$ & $(0.0887)$ & $(0.0894)$ & $(0.0871)$ \\
\hline \multirow[t]{2}{*}{ Securityreturn } & $0.595 * * *$ & $0.359 * *$ & $0.354 * *$ & $0.572 * * *$ & $0.362 * *$ & $0.355 * *$ \\
\hline & $(0.167)$ & $(0.156)$ & $(0.155)$ & $(0.166)$ & $(0.156)$ & $(0.155)$ \\
\hline Observations & 165 & 164 & 163 & 165 & 164 & 163 \\
\hline Pseudo R2 & 0.0798 & 0.0386 & 0.0461 & 0.0742 & 0.0382 & 0.0457 \\
\hline LR Chi2 & 40.94 & 23.92 & 30.28 & 38.08 & 23.71 & 30.07 \\
\hline Prob < Chi2 & $9.74 \mathrm{e}-05$ & 0.0318 & 0.00430 & 0.000149 & 0.0223 & 0.00272 \\
\hline
\end{tabular}

Standard errors in parentheses

$* * * p<0.01, * * p<0.05, * p<0.1$ 
Table 6 Results for financial return crowdfunding

\begin{tabular}{|c|c|c|c|c|c|c|}
\hline Variables & Infoprojobj & Infopersprev & Infofinrisk & Infoprojobj & Infopersprev & Infofinrisk \\
\hline \multirow[t]{2}{*}{ Strongties } & 1.363 & $2.714 * *$ & $-2.158 *$ & & & \\
\hline & $(1.343)$ & $(1.114)$ & $(1.236)$ & & & \\
\hline \multirow[t]{2}{*}{ Weakties } & 0.989 & 0.899 & -0.669 & & & \\
\hline & $(0.797)$ & $(0.745)$ & $(0.720)$ & & & \\
\hline \multirow[t]{2}{*}{ Noties } & & & & -1.030 & $-1.187 *$ & 0.746 \\
\hline & & & & $(0.787)$ & $(0.720)$ & $(0.718)$ \\
\hline \multirow[t]{2}{*}{ Keepinmindrisk } & 0.542 & -0.368 & 0.190 & 0.546 & -0.266 & 0.119 \\
\hline & $(0.497)$ & $(0.458)$ & $(0.457)$ & $(0.496)$ & $(0.448)$ & $(0.449)$ \\
\hline \multirow[t]{2}{*}{ Knowingfincontriboth } & 0.285 & 0.158 & $0.743 * *$ & 0.292 & 0.193 & $0.667 * *$ \\
\hline & $(0.290)$ & $(0.265)$ & $(0.294)$ & $(0.290)$ & $(0.266)$ & $(0.281)$ \\
\hline \multirow[t]{2}{*}{ Profit } & 0.832 & 0.534 & 0.199 & 0.852 & 0.600 & 0.121 \\
\hline & (1.107) & $(0.952)$ & $(0.933)$ & (1.111) & $(0.938)$ & $(0.931)$ \\
\hline \multirow[t]{2}{*}{ Social } & 0.446 & 0.100 & -0.112 & 0.483 & 0.167 & -0.136 \\
\hline & $(0.943)$ & $(0.827)$ & $(0.825)$ & $(0.937)$ & $(0.811)$ & $(0.831)$ \\
\hline \multirow[t]{2}{*}{ Cultural } & -0.0182 & -0.964 & 1.277 & 0.0300 & -0.844 & 1.030 \\
\hline & (1.509) & $(1.350)$ & (1.348) & (1.499) & $(1.317)$ & $(1.322)$ \\
\hline \multirow[t]{2}{*}{ Ecological } & -0.975 & $-1.529 * *$ & 1.214 & -0.894 & -1.184 & 0.793 \\
\hline & $(0.889)$ & $(0.779)$ & $(0.801)$ & $(0.849)$ & $(0.742)$ & $(0.730)$ \\
\hline \multirow[t]{2}{*}{ Amount } & -0.255 & 0.00886 & $0.316 * *$ & -0.245 & 0.0515 & $0.264 *$ \\
\hline & $(0.167)$ & $(0.149)$ & $(0.152)$ & $(0.164)$ & $(0.144)$ & $(0.145)$ \\
\hline \multirow[t]{2}{*}{ Gender } & $1.624 *$ & 0.294 & -1.085 & $1.592 *$ & 0.245 & -0.913 \\
\hline & $(0.838)$ & $(0.718)$ & $(0.730)$ & $(0.828)$ & $(0.701)$ & $(0.711)$ \\
\hline \multirow[t]{2}{*}{ Age } & $1.037 * * *$ & 0.360 & -0.235 & $1.051 * * *$ & 0.454 & -0.281 \\
\hline & $(0.380)$ & $(0.308)$ & $(0.313)$ & $(0.379)$ & $(0.305)$ & $(0.309)$ \\
\hline \multirow[t]{2}{*}{ Education } & -0.121 & -0.0629 & $-0.463 * *$ & -0.124 & -0.0640 & $-0.410 *$ \\
\hline & $(0.248)$ & $(0.200)$ & $(0.230)$ & $(0.248)$ & $(0.197)$ & $(0.224)$ \\
\hline \multirow[t]{2}{*}{ Securityreturn } & $0.866^{* *}$ & $1.057 * * *$ & 0.288 & $0.846^{*}$ & $0.938 * * *$ & 0.400 \\
\hline & $(0.435)$ & $(0.355)$ & $(0.373)$ & $(0.433)$ & $(0.350)$ & $(0.363)$ \\
\hline Observations & 48 & 49 & 48 & 48 & 49 & 48 \\
\hline Pseudo R2 & 0.211 & 0.150 & 0.157 & 0.210 & 0.125 & 0.144 \\
\hline LR Chi2 & 22.62 & 22.78 & 23.13 & 22.52 & 18.98 & 21.21 \\
\hline Prob < Chi2 & 0.0465 & 0.0444 & 0.0402 & 0.0321 & 0.0890 & 0.0474 \\
\hline
\end{tabular}

Standard errors in parentheses

$* * * p<0.01, * * p<0.05, * p<0.1$ 
Open Access This article is distributed under the terms of the Creative Commons Attribution 4.0 International License (http:// creativecommons.org/licenses/by/4.0/), which permits unrestricted use, distribution, and reproduction in any medium, provided you give appropriate credit to the original author(s) and the source, provide a link to the Creative Commons license, and indicate if changes were made.

\section{References}

Agrawal, A. K., Catalini, C., \& Goldfarb, A. (2015). Crowdfunding: geography, social networks, and the timing of investment decisions. Journal of Economics \& Management Strategy, 24(2), 253-274. doi:10.1111/jems.12093.

Agresti, A. (2010). Analysis of ordinal categorical data. Hoboken: Wiley.

Ahlers, G. K. C., Cumming, D., Günther, C., \& Schweizer, D. (2015). Signaling in equity crowdfunding. Entrepreneurship Theory and Practice, 39(4), 955-980. doi:10.1111 /etap. 12157.

Akerlof, G. A. (1970). The market for "lemons": quality uncertainty and the market mechanism. The Quarterly Journal of Economics, 84(3), 488-500. doi:10.2307/1879431.

Aldrich, H. E., \& Ruef, M. (2006). Organizations evolving. London: Sage.

Alexy, O., Block, J., Sandner, P., \& Ter Wal, A. (2012). Social capital of venture capitalists and start-up funding. Small Business Economics, 39, 835-851. doi:10.1007/s11187011-9337-4.

Allison, T. H., Davis, B. C., Short, J. C., \& Webb, J. W. (2015). Crowdfunding in a prosocial microlending environment: examining the role of intrinsic versus extrinsic cues. Entrepreneurship Theory and Practice, 39(1), 53-73. doi:10.1111/etap.12108.

Amit, R., Glosten, L., \& Muller, E. (1990). Entrepreneurial ability, venture investments, and risk sharing. Management Science, 36(10), 1232-1245. doi:10.1287/mnsc.36.10.1233

Andreoni, J. (1990). Impure altruism and donations to public goods: a theory of warm-glow giving. The Economic Journal, 100(401), 464-477. doi:10.2307/2234133.

Apinunmahakul, A., \& Devlin, R. A. (2008). Social networks and private philanthropy. Journal of Public Economics, 92(1-2), 309-328. doi:10.1016/j.jpubeco.2007.07.005.

Audretsch, D. B., Bönte, W., \& Mahagaonkar, P. (2012). Financial signaling by innovative nascent ventures: the relevance of patents and prototypes. Research Policy, 41(8), 1407-1421. doi:10.1016/j.respol.2012.02.003.

Beck, T., \& Demirguc-Kunt, A. (2006). Small and medium-size enterprises: access to finance as a growth constraint. Journal of Banking \& Finance, 30(11), 2931-2943. doi:10.1016/j. jbankfin.2006.05.009.

Becker-Blease, J. R., \& Sohl, J. E. (2015). New venture legitimacy: the conditions for angel investors. Small Business Economics, 45(4), 735-749. doi:10.1007 /s11187-015-9668-7.
Belleflamme, P., Lambert, T., \& Schwienbacher, A. (2013). Individual crowdfunding practices. Venture Capital, 15(4), 313-333. doi:10.1080/13691066.2013.785151.

Belleflamme, P., Lambert, T., \& Schwienbacher, A. (2014). Crowdfunding: tapping the right crowd. Journal of Business Venturing, 29(5), 585-609. doi:10.1016/j. jbusvent.2013.07.003.

Bernstein, S., Giroud, X., \& Townsend, R. R. (2016a). The impact of venture capital monitoring. The Journal of Finance, 71(4), 1591-1622. doi: 10.1111/jofi.12370.

Bernstein, S., Korteweg, A. G., \& Laws, K. (2016b). Attracting early stage investors: evidence from a randomized field experiment. Journal of Finance. doi:10.1111/jofi.12470.

Bhidé, A. (2010). A call for judgment: sensible finance for a dynamic economy. Oxford: Oxford University Press.

Bikhchandani, S., Hirshleifer, D., \& Welch, I. (1992). A theory of fads, fashion, custom, and cultural change as informational cascades. Journal of Political Economy, 100(5), 992-1026.

Binks, M. R., \& Ennew, C. T. (1996). Growing firms and the credit constraint. Small Business Economics, 8(1), 17-25. doi:10.1007/BF00391972.

Block, J., \& Sandner, P. (2009). What is the effect of the financial crisis on venture capital financing? Empirical evidence from US internet start-ups. Venture Capital, 11(4), 295-309. doi:10.1080/13691060903184803.

Blumberg, B. F., \& Letterie, W. A. (2007). Business starters and credit rationing. Small Business Economics, 30(2), 187-200. doi:10.1007/s11187-006-9030-1.

Boot, A. W. A. (2000). Relationship banking: what do we know? Journal of Financial Intermediation, 9(1), 7-25. doi:10.1006 /jfin.2000.0282.

Bosma, N., Praag, M. van, Thurik, R., \& Wit, G. de. (2004). The value of human and social capital investments for the business performance of startups. Small Business Economics, 23(3), 227-236. doi:10.1023/B:SBEJ.0000032032.21192.72

Brancati, E. (2014). Innovation financing and the role of relationship lending for SMEs. Small Business Economics, 44(2), 449-473. doi:10.1007/s11187-014-9603-3.

Bruton, G., Khavul, S., Siegel, D., \& Wright, M. (2015). New financial alternatives in seeding entrepreneurship: microfinance, crowdfunding, and peer-to-peer innovations. Entrepreneurship Theory and Practice, 39(1), 9-26. doi:10.1111/etap.12143.

Burtch, G., Ghose, A., \& Wattal, S. (2013). An empirical examination of the antecedents and consequences of contribution patterns in crowd-funded markets. Information Systems Research, 24(3), 499-519. doi:10.1287/isre.1120.0468.

Burtch, G., Ghose, A., \& Wattal, S. (2015). The hidden cost of accommodating crowdfunder privacy preferences: a randomized field experiment. Management Science, 61(5), 949-962. doi:10.1287/mnsc.2014.2069.

Busenitz, L. W., Fiet, J. O., \& Moesel, D. D. (2005). Signaling in venture capitalist - new venture team funding decisions: does it indicate long-term venture outcomes? Entrepreneurship Theory and Practice, 29(1), 1-12. doi:10.1111/j.1540-6520.2005.00066.x.

Calic, G., \& Mosakowski, E. (2016). Kicking off social entrepreneurship: how a sustainability orientation influences crowdfunding success. Journal of Management Studies, 53(5), 738-767. doi:10.1111/joms.12201. 
Cassar, G. (2004). The financing of business start-ups. Journal of Business Venturing, 19(2), 261-283. doi:10.1016/S08839026(03)00029-6.

Centola, D., \& Macy, M. (2007). Complex contagions and the weakness of long ties. American Journal of Sociology, 113(3), 702-734. doi:10.1086/521848.

Chittenden, F., Hall, G., \& Hutchinson, P. (1996). Small firm growth, access to capital markets and financial structure: review of issues and an empirical investigation. Small Business Economics, 8(1), 59-67. doi:10.1007/BF00391976.

Cholakova, M., \& Clarysse, B. (2015). Does the possibility to make equity investments in crowdfunding projects crowd out reward-based investments? Entrepreneurship Theory and Practice, 39(1), 145-172. doi:10.1111/etap.12139.

Colombo, M. G., Franzoni, C., \& Rossi-Lamastra, C. (2015). Internal social capital and the attraction of early contributions in crowdfunding. Entrepreneurship Theory and Practice, 39(1), 75-100. doi:10.1111/etap.12118.

Cosci, S., Meliciani, V., \& Sabato, V. (2016). Relationship lending and innovation: empirical evidence on a sample of European firms. Economics of Innovation and New Technology, 25(4), 335-357. doi:10.1080/10438599.2015.1062098.

Cowling, M., Liu, W., Minniti, M., \& Zhang, N. (2016). UK credit and discouragement during the GFC. Small Business Economics, 1-26. doi:10.1007/s11187-016-9745-6.

Cumming, D. J., Leboeuf, G., \& Schwienbacher, A. (2015a). Crowdfunding models: keep-it-all vs. all-or-nothing. SSRN eLibrary. http://papers.ssrn.com/sol3/Papers.cfm?abstract_ $\mathrm{id}=2447567$. Accessed 20 April 2016

Cumming, D. J., Pandes, J. A., \& Robinson, M. J. (2015b). The role of agents in private entrepreneurial finance. Entrepreneurship Theory and Practice, 39(2), 345-374. doi:10.1111/etap.12043.

Davidsson, P., \& Honig, B. (2003). The role of social and human capital among nascent entrepreneurs. Journal of Business Venturing, 18(3), 301-331. doi:10.1016/S0883-9026(02 )00097-6.

Dellarocas, C. (2003). The digitization of word of mouth: promise and challenges of online feedback mechanisms. Management Science, 49(10), 1407-1424. doi:10.1287 /mnsc.49.10.1407.17308.

Denis, D. J. (2004). Entrepreneurial finance: an overview of the issues and evidence. Journal of Corporate Finance, 10(2), 301-326. doi:10.1016/S0929-1199(03)00059-2.

Dillman, D. A. (2000). Mail and internet surveys. New York: Wiley.

Dubini, P., \& Aldrich, H. (1991). Personal and extended networks are central to the entrepreneurial process. Journal of Business Venturing, 6(5), 305-313. doi:10.1016/0883-9026(91 )90021-5.

Ebben, J., \& Johnson, A. (2006). Bootstrapping in small firms: an empirical analysis of change over time. Journal of Business Venturing, 21(6), 851-865. doi:10.1016/j. jbusvent.2005.06.007.

Engel, D., \& Stiebale, J. (2014). Private equity, investment and financial constraints: firm-level evidence for France and the United Kingdom. Small Business Economics, 43, 197-212. doi:10.1007/s11187-013-9530-8.

Gartner, W. B., Frid, C. J., \& Alexander, J. C. (2011). Financing the emerging firm. Small Business Economics, 39(3), 745761. doi:10.1007/s11187-011-9359-y.
Giudici, G., \& Paleari, S. (2000). The provision of finance to innovation: a survey conducted among Italian technologybased small firms. Small Business Economics, 14(1), 37-53. doi:10.1023/A:1008187416389.

Gompers, P. A. (1995). Optimal investment, monitoring, and the staging of venture capital. The Journal of Finance, 50(5), 1461-1489. doi:10.2307/2329323.

Gompers, P. A., \& Lerner, J. (2001). The venture capital revolution. The Journal of Economic Perspectives, 15(2), 145-168.

Granovetter, M. S. (1973). The strength of weak ties. American Journal of Sociology, 78(6), 1360-1380.

Granovetter, M. (1985). Economic action and social structure: the problem of embeddedness. American Journal of Sociology, 91(3), 481-510.

Granovetter, M. (2005). The impact of social structure on economic outcomes. The Journal of Economic Perspectives, 19(1), 33-50. doi:10.1257/0895330053147958.

Hair, J. (2010). Multivariate data analysis: a global perspective. (7th ed.). Upper Saddle River, London: Pearson Education.

Hall, B. H. (2002). The financing of research and development (Working Paper No. 8773). Cambridge: National Bureau of Economic Research. http://www.nber.org/papers/w8773

Harrison, R. T. (2013). Crowdfunding and the revitalisation of the early stage risk capital market: catalyst or chimera? Venture Capital, 15(4), 283-287. doi:10.1080 /13691066.2013.852331.

Hildebrand, T., Puri, M., \& Rocholl, J. (2016). Adverse incentives in crowdfunding. Management Science. doi:10.1287 /mnsc.2015.2339.

Hoang, H., \& Antoncic, B. (2003). Network-based research in entrepreneurship: a critical review. Journal of Business Venturing, 18(2), 165-187. doi:10.1016/S0883-9026(02 )00081-2.

Hörisch, J. (2015). Crowdfunding for environmental ventures: an empirical analysis of the influence of environmental orientation on the success of crowdfunding initiatives. Journal of Cleaner Production, 107, 636-645. doi:10.1016/j. jclepro.2015.05.046.

Hornuf, L., \& Schwienbacher, A. (2015). Funding dynamics in crowdinvesting (SSRN Scholarly Paper No. ID 2612998). Rochester: Social Science Research Network. http://papers.ssrn.com/abstract $=2612998$. Accessed 20 April 2016

Horvát, E.-Á., Uparna, J., \& Uzzi, B. (2015). Network vs market relations: the effect of friends in crowdfunding. In Proceedings of the 2015 IEEE/ACM international conference on advances in social networks analysis and mining 2015 (pp. 226-233). New York: ACM. doi:10.1145 /2808797.2808904.

Huang, L., \& Knight, A. (2015). Resources and relationships in entrepreneurship: an exchange theory of the development and effects of the entrepreneur-investor relationship. Academy of Management Review. doi:10.5465 /amr.2014.0397.

Hui, J. S., Gerber, E. M., \& Gergle, D. (2014). Understanding and leveraging social networks for crowdfunding: opportunities and challenges. In Proceedings of the 2014 conference on designing interactive systems (pp. 677-680). New York: ACM. doi:10.1145/2598510.2598539.

Huyghebaert, N., de Gucht, L. V., \& Hulle, C. V. (2007). The choice between bank debt and trade credit in business start- 
ups. Small Business Economics, 29(4), 455-455. doi:10.1007/s11187-007-9070-1.

Jack, S. L., \& Anderson, A. R. (2002). The effects of embeddedness on the entrepreneurial process. Journal of Business Venturing, 17(5), 467-487. doi:10.1016/S08839026(01)00076-3.

Jensen, M. C., \& Meckling, W. H. (1976). Theory of the firm: managerial behavior, agency costs and ownership structure. Journal of Financial Economics, 3(4), 305-360. doi:10.1016 /0304-405X(76)90026-X.

Jick, T. D. (1979). Mixing qualitative and quantitative methods: triangulation in action. Administrative Science Quarterly, 24(4), 602-611. doi:10.2307/2392366.

Keasey, K., \& McGuinness, P. (1990). Small new firms and the return to alternative sources of finance. Small Business Economics, 2(3), 213-222. doi:10.1007/BF00389529.

Kerr, W. R., Lerner, J., \& Schoar, A. (2014). The consequences of entrepreneurial finance: evidence from angel financings. Review of Financial Studies, 27(1), 20-55. doi:10.1093/rfs/hhr098.

Klyver, K., Lindsay, N. J., Kassicieh, S. K. "Sul,” \& Hancock, G. (2016). Altruistic investment decision behavior in early-stage ventures. Small Business Economics, 1-18. doi:10.1007 /s11187-016-9771-4

Kortum, S., \& Lerner, J. (2000). Assessing the contribution of venture capital to innovation. The Rand Journal of Economics, 31(4), 674-692. doi:10.2307/2696354.

Kuppuswamy, V., \& Bayus, B. L. (2015). Crowdfunding creative ideas: the dynamics of project backers in kickstarter (SSRN scholarly paper no. ID 2234765). Rochester: Social Science Research Network. http://papers.ssrn. com/abstract=2234765. Accessed 20 April 2016

Kutner, M. H., Nachtsheim, C. J., Neter, J., \& Li, W. (2005). Applied linear statistical models (5th ed.). New York: McGraw-Hill.

Kwon, S.-W., \& Arenius, P. (2010). Nations of entrepreneurs: a social capital perspective. Journal of Business Venturing, 25(3), 315-330. doi:10.1016/j.jbusvent.2008.10.008.

Lin, M., Prabhala, N. R., \& Viswanathan, S. (2012). Judging borrowers by the company they keep: friendship networks and information asymmetry in online peer-to-peer lending. Management Science, 59(1), 17-35. doi:10.1287 /mnsc. 1120.1560 .

Maas, K., \& Liket, K. (2010). Talk the walk: measuring the impact of strategic philanthropy. Journal of Business Ethics, 100(3), 445-464. doi:10.1007/s10551-010-0690-z.

Manigart, S., \& Wright, M. (2011). Reassessing the relationships between private equity investors and their portfolio companies. Small Business Economics, 40(3), 479-492. doi:10.1007/s11187-011-9387-7.

Massolution. (2015). Crowdfunding Industry Report: Market Trends, Composition and Crowdfunding Platforms. Los Angeles: Crowdsoucring LLC

Migendt, M., Schock, F., Täube, F. A., von Flotow, P., \& Polzin, F. (2014). Private equity in clean technology: an exploratory study of the finance-innovation-policy nexus (SSRN scholarly paper no. ID 2501297). Rochester: Social Science Research Network. http://papers.ssrn. com/abstract $=2501297$. Accessed 6 October 2014

Mollick, E. R. (2014). The dynamics of crowdfunding: an exploratory study. Journal of Business Venturing, 29(1), 1-16. doi:10.1016/j.jbusvent.2013.06.005.
Mollick, E. R. (2015). Delivery rates on kickstarter (SSRN scholarly paper no. ID 2699251). Rochester: Social Science Research Network. http:// papers.ssrn. com/abstract=2699251. Accessed 31 May 2016

Mollick, E. R., \& Nanda, R. (2015). Wisdom or madness? Comparing crowds with expert evaluation in funding the arts. Management Science. doi:10.1287/mnsc.2015.2207.

Moritz, A., \& Block, J. H. (2016). Crowdfunding: a literature review and research directions. In: D. Brüntje \& O. Gajda (Eds.), Crowdfunding in Europe (pp. 25-53). Springer.

Moritz, A., Block, J., \& Lutz, E. (2015). Investor communication in equity-based crowdfunding: a qualitative-empirical study. Qualitative Research in Financial Markets, 7(3), 309-342. doi:10.1108/QRFM-07-2014-0021.

Myers, S. C., \& Majluf, N. S. (1984). Corporate financing and investment decisions when firms have information that investors do not have. Journal of Financial Economics, 13(2), 187-221. doi:10.1016/0304-405X(84)90023-0.

Nesta. (2014). Understanding alternative finance: the UK alternative finance industry report 2014. London: Nesta.

Ordanini, A., Miceli, L., Pizzetti, M., \& Parasuraman, A. (2011). Crowd-funding: transforming customers into investors through innovative service platforms. Journal of Service Management, 22(4), 443-470. doi:10.1108 /09564231111155079.

Ouimet, P., \& Zarutskie, R. (2014). Who works for startups? The relation between firm age, employee age, and growth. Journal of Financial Economics, 112(3), 386-407. doi:10.1016/j.jfineco.2014.03.003.

Parker, S. C. (2009). The Economics of Entrepreneurship. Cambridge: Cambridge University Press.

Patton, M. Q. (2002). Qualitative research and evaluation methods. CA: SAGE Thousand Oaks

Podsakoff, P. M., MacKenzie, S. B., Lee, J.-Y., \& Podsakoff, N. P. (2003). Common method biases in behavioral research: a critical review of the literature and recommended remedies. Journal of Applied Psychology, 88(5), 879-903. doi:10.1037 /0021-9010.88.5.879.

Pukthuanthong, K. (2006). Underwriter learning about unfamiliar firms: evidence from the history of biotech IPOS. Journal of Financial Markets, 9(4), 366-407. doi:10.1016/j. finmar.2006.05.002.

Rostamkalaei, A., \& Freel, M. (2015). The cost of growth: small firms and the pricing of bank loans. Small Business Economics, 46(2), 255-272. doi:10.1007/s11187-015-9681$\mathrm{x}$.

Salomon, V. (2016). Emergent models of financial intermediation for innovative companies: from venture capital to crowdinvesting platforms in Switzerland. Venture Capital, 18(1), 21-41. doi:10.1080/13691066.2015.1079953.

Samila, S., \& Sorenson, O. (2010). Venture capital as a catalyst to commercialization. Research Policy, 39(10), 1348-1360. doi:10.1016/j.respol.2010.08.006.

Scholtens, B. (1999). Analytical issues in external financing alternatives for SBEs. Small Business Economics, 12(2), 137148. doi:10.1023/A:1008045531070.

Shane, S., \& Cable, D. (2002). Network ties, reputation, and the financing of new ventures. Management Science, 48(3), 364 381.

Sorenson, O., \& Stuart, T. E. (2008). Bringing the context back in: settings and the search for syndicate partners in venture 
capital investment networks. Administrative Science Quarterly, 53(2), 266-294. doi:10.2189/asqu.53.2.266.

Spence, M. (1973). Job market signaling. The Quarterly Journal of Economics, 87(3), 355-374. doi:10.2307/1882010.

Stiglitz, J. E., \& Weiss, A. (1981). Credit rationing in markets with imperfect information. The American Economic Review, 71(3), 393-410.

Surowiecki, J. (2005). The wisdom of crowds. New York: Anchor Books.

Ter Wal, A. L. J., Alexy, O., Block, J., \& Sandner, P. G. (2016). The best of both worlds the benefits of open-specialized and closed-diverse syndication networks for new ventures' success. Administrative Science Quarterly. doi:10.1177 /0001839216637849.

Uzzi, B. (1999). Embeddedness in the making of financial capital: how social relations and networks benefit firms seeking financing. American Sociological Review, 64(4), 481-505. doi: $10.2307 / 2657252$.

Vismara, S. (2016a). Equity retention and social network theory in equity crowdfunding. Small Business Economics, 46(4), 579-590. doi:10.1007/s11187-016-9710-4.

Vismara, S. (2016b). Information cascades among investors in equity crowdfunding. Entrepreneurship Theory and Practice. Forthcoming.

Wardrop, R., Zhang, B., Rau, R., \& Gray, M. (2015). Moving mainstream: the European alternative finance benchmarking report. Cambridge: University of Cambridge.

Yao-Wen, H. (2010). Staging of venture capital investment: a real options analysis. Small Business Economics, 35(3), 265-281. doi:10.1007/s11187-008-9158-2 